\title{
Polymorphy and extinction of the Late Cretaceous burrowing shrimp Protocallianassa faujasi and first record of the genera Corallianassa and Calliax (Crustacea, Decapoda, Thalassinoidea) from the Cretaceous
}

\author{
Krista Swen ${ }^{1}$, René H.B. Fraaije ${ }^{2}$ \& Gijssbert J. van der Zwaan ${ }^{1,3}$ \\ 'Department of Ecology/Biogeology, University of Nijmegen, Toernooiveld 1, 6525 ED Nijmegen, \\ The Netherlands; '2Oertijdmuseum De Groene Poort, Bosscheweg 80, 5283 WB Boxtel, The Netherlands, \\ E-mail: info@oertijdmuseum.nl; ${ }^{3}$ Department of Geology, IVAU, Utrecht University, Budapestlaan 4, 3508 \\ TA Utrecht, The Netherlands, E-mail: bzwaan@geo.uu.nl
}

Keywords: Thalassinoidea, Cretaceous, polymorphy, new species

\section{Abstract}

A biometric study of chelae of the burrowing shrimp Protocallianassa faujasi (Desmarest, 1822), from the late Maastrichtian of the Maastrichtian type area, The Netherlands, has revealed three morphotypes. These types are interpreted as sexual dimorphs (male and female) and earliest ecdysis stages (immature male). Among the studied material are fifteen specimens of a new Cretaceous callianassid, Corallianassa acucurvata new specíes, one specimen provisionally assigned to the genus Calliax and a callianassid from the Danian.

Burrows preserving callianassid chelae in situ are discussed. Based on burrow morphology a suspension feeding mode of life for $P$. faujasi is inferred, whereas $C$. acucurvata $n$. sp. probably was an active omnivorous analogue of its closest Recent relatives. The extinction of $P_{x}$ faujasi in the Meerssen Member appears to correspond to the increase in seagrass vegetation. The Protocallianassa-Corallianassa faunal changeover took place about 100,000 yrs before the $\mathrm{K} / \mathrm{T}$ boundary in this region.

\section{Contents}

Abstract

Introduction

Material

Method

Results

Systematic palaeontology

assa acucurvata $\mathrm{n}$. sp.

Burrows

Conclusions

Acknowledgments

References

\section{Introduction}

Isolated chelae assigned to the genus Protocallianassa, are among the most abundant of all fossil decapod crustaceans in the Maastrichtian type area. Their burtowing habit in areas of active sedimentation (Zijlstra, 1994), together with strong calcification of the claws and fingers which were used in burrowing, protected them against taphonomic destruction (Fraaye, 1996a). Of these animal remains, usually only the first pereiopod pair, which is strongly calcified, is preserved. The remainder of the exoskeleton was weakly calcified, as in Recent callianassids (e.g., Mulder, 1981). There is no need for a fully calcified exoskeleton since they have adopted a fossorial mode of life, living in usually complex burrow systems (e.g., Griffis \& Suchanek, 1991).

As a result of selective preservation, a large number of fossil callianassids have been described on the basis of (parts of) chelae and other isolated fragments. Only very few species of the genus Protocallianassa are based on more or less complete specimens (Beikirch \& Feldmann, 1980). In the absence of abdomen and cephalothorax it is often difficult to distinguish the various fossil callianassids. Within the Callianassidae five subfamilies are currently recognised: Callianassinae, Callichirinae, Cheraminae, Eucalliinae, and Protocallianassinae (Manning \& Felder, 1991). Manning and Felder's (1991) revision did not ínclude fossil taxa. Their biological taxonomic framework is based on such features as anterior carapace regions, abdomen and tail fan structures, third maxilliped 
morphology, and nature of antennae and cornae, which only perfectly preserved fossil specimens might display. However, they did illustrate first major chelipeds of most of their genera, and these seem to be directly comparable with equivalent fossil remains (Vega et al., 1995; Toolson \& Kues, 1996).

Protocallianassa is the only genus in the subfamily Protocallianassinae; it ranges from the Barremian to the Eocene (Feldmann \& Wilson, 1988; Aguirre-Urreta, 1989). Callianassa, the sole species in the Callianassinae, is known from at least the Albian onwards (Aguirre-Urreta, 1989). All Recent American species formerly assigned to $\mathrm{Cal}$ lianassa were referred to other genera by Manning and Felder (1991), leaving only a single Recent species within this genus: Callianassa subterranea, known from the eastern Atlantic and Mediterranean. Of the other taxa Cheramus, type genus of the Cheraminae, has been recorded from the Maastrichtian of Mexico and from the Eocene of Antarctica (Vega et al., 1995). So far no fossil members of the Eucalliinae and Callichirinae were reported. Corallianassa acucurvata n. sp. and Calliax? sp. thus represent the first record of the Callichirinae and Eucalliinae from the late Cretaceous.

Mertin (1941) proposed five criteria to distinguish between Callianassa and Protocallianassa species. The latter have: 1 , a relatively elongated claw; 2, no indentation on the front side of the manus; 3 , a diagonal connection between the carpus and propodus; 4 , a carpus narrower than the manus and often almost as long; 5 , no lateral protrusions from the merus.

Glaessner (1969), however, considered a distinction between callianassid genera on the basis of isolated chelae to be impossible. Among others, Vega et al. (1995) took the angle of the carpuspropodus joint to be a reliable characteristic for distinction between the two genera, and in this we concur.

During the last decade a large number of decapod crustaceans with many new species were collected in stratigraphical order from the Maastrichtian stratotype area and deposited in the Oertijdmuseum "De Groene Poort" (formerly Geo Centrum Brabant) collections (Fraaye \& Collins, 1987; Jagt, Collins
\& Fraaye, 1991; Collins, Fraaye \& Jagt, 1995; Fraaye, 1996 a, b, c, d; Jagt, Fraaye \& van Bakel, 2000). The abundant and apparently polymorphic callianassids from these collections were conspicious, and they were analysed biometrically.

Sexual dimorphism in major callianassid chelipeds has been documented in several biological studies (e.g. Poore, 1975; Sakai, 1969) and only recently in a palaeontological study of Cenozoic decapods from the state of Washington, USA (Schweitzer Hopkins \& Feldmann, 1997). Recent examples of sexual polymorphy were reported by Dworschak and Pervesler, 1988 (2 male and 2 female types) for Callianassa bouvieri from the Red Sea and by Sakai (1969) for C. japonica (2 male and 1 female types) and $C$. petalura from Japanese waters. Before 1960 taxonomists have paid no attention to sexual differences among recent callianassid species and consequently the number of species described and named was enormous (see Sakai, 1969, p. 231). Such taxonomic problems also hamper paleontological studies and this has led to one of the most inconsistent and confusing systematics among this group of fossil decapod crustaceans (e.g., Toolson \& Kues, 1996).

Although Mertĩn (1941) already hinted at a case of possible sexual dimorphism in fossil callianassid chelae, no such previous studies of Cretaceous material are known to us. Among others, Roberts (1962), Bishop (1985) and Aguirre-Urreta (1989) noted the wide range of morphological variation of Cretaceous callianassid chelae. The first-named distinguished two "races" among specimens of late Cretaceous Protocallianassa mortoni from New Jersey and Delaware, USA, the second suggested that detailed shape analysis of large suites of specimens would be necessary to place the systematics of this family on a firmer basis, while the lastnamed noted differences between males and females. With the present report we hope to trigger further biometric studies in order to unravel this worldwide taxonomic puzzle.

The heterochelous Protocallianassa faujasi (Desmarest, 1822) from the Maastìchtian stratotype area is, together with Protocallianassa sp. from the Maastrichtian of Mexico, the youngest known member of the genus on the northern hemisphere. The last records of $P$. faujasi in Western Europe 
are from the late Maastrichtian upper Nekum and lower Meerssen Members (Belemnitella junior Zone). In the northern hemisphere their habitat seems to have been taken over by other more successful callianassids such as Callianassa, Cheramus, Corallianassa and Calliax from that time onwards. Based on the data published by Feldmann et al. (1995) and Aguirre-Urreta (1989), the faunal changeover of the Protocallianassinae by the other subfamilies of the Callianassidae probably occurred during the Paleocene in Argentina and during the Eocene in the southernmost region (Antarctica and New Zealand).

Due to their peculiar mode of life Corallianassa and related genera have survived to the present, within a restricted habitat, but with a cosmopolitan distribution (e.g. Aguirre-Urreta, 1989; Manning \& Felder, 1991).

\section{Material}

For this biometric study 214 more or less complete pereiopod pairs of Protocallianassa faujasi were available. Two specimens are from the Emael Member, 111 specimens from the Nekum Member and one from the Meerssen Member (Oertijdmuseum De Groene Poort, Boxtel collections). Of the remaining 102 specimens (Natuurhistorisch Museum Maastricht, L. Indeherberge and $\mathrm{M}$. Kupyers collections) details of stratigraphical provenance were lacking but matrix and nature of preservation strongly suggest a Nekum Member provenance. The specimens were collected in several quarries in the Maastrichtian stratotype area of southern Limburg, The Netherlands, and northeastern Belgium (see Collins, Fraaye \& Jagt, 1995, p. 168, 170-171). For a reference, two casts of respectively $P$. mortoni and $P$. russelli from the late Cretaceous of the USA (kindly provided by G.A. Bishop) were used.

Small epizoic serpulids (Cementula? sp.) often occur on $P$. faujasi pereiopods (Plate 2, Figs. 3, 5-7), and are generally concentrated on the central outer parts of the propodus and dactylus. Decapod crustaceans have effectively morphological and behaviourial adaptations to remove epizoans (Bauer, 1980), therefore the common occurrence of epizoic serpulids on $P$. falljasi could be indicative of a commensal relationship which needs further investigation. No epizoans were recorded on Corallianassa acucurvata $\mathrm{n}$. sp. Another common serpulid-decapod relationship known from the late Cretaceous is that of the epizoic serpulid Rotularia sp. on the lobster Hoploparia stokesi (Tshudy « Feldmann, 1988).

\section{Method}

Measurements of the first pereiopod pair were obtained as shown in Fig. 1. Lengths were measured with an error of $0.5 \mathrm{~mm}$ and angles have an error of one degree. Large claw-1, propodus length; 2 , manus length; 3 , dactylus length; 4 , front manus width; 5, distal manus width; 6, carpus length; 7, merus length. Small claw-8, propodus length; 9, manus length; 10 , dactylus length; 11 , front manus width; 12, distal manus width; Angle-13, between proximal and lower edge of propodus of large claw; 14 , between proximal and lower edge of propodus of small claw.

Other data recorded were: Large claw-15, left or right handed; 16 , general shape of dactylus and index; 17 , ornamentation of propodus surface.

All data gathered from the specimens were treated statistically using the statistical package SPSS. A selection of the most relevant results is given in Figs. 2 and 3.

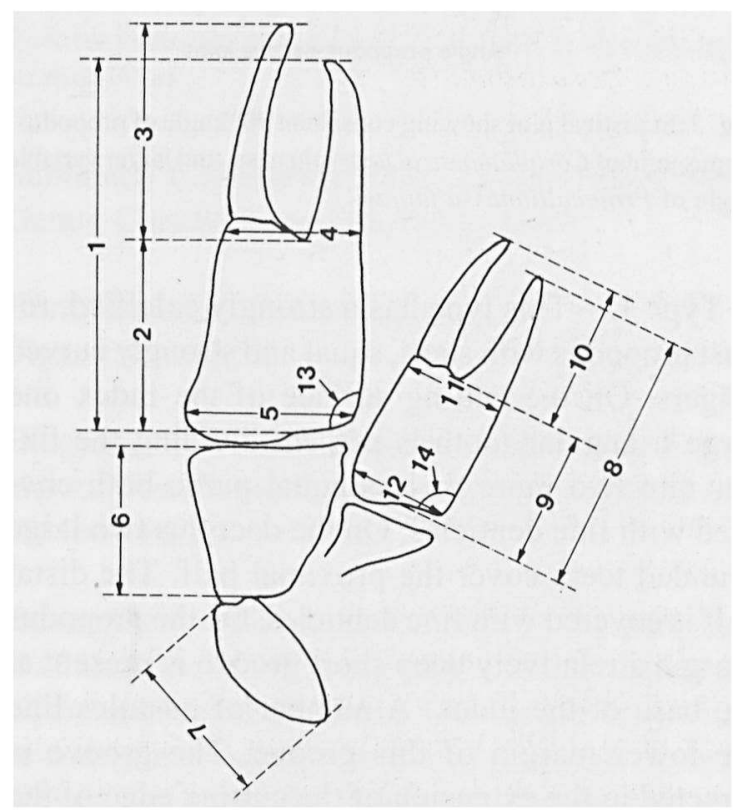

Fig. 1. Pereiopod measurements used in this study.

\section{Results}

The biometric and morphological data reveal a clear division into three morphotypes for the large claw in Protocallianassa faujasi assemblages (Figs. 2, $3,4.1-4.3)$. 


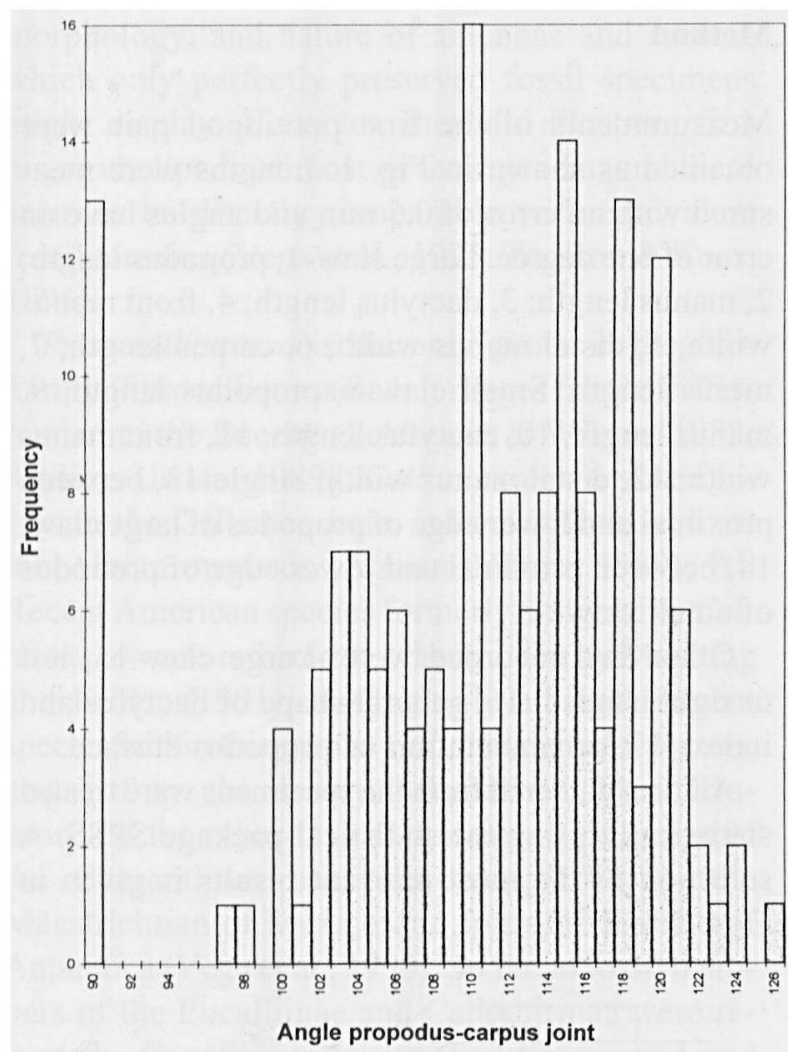

Fig. 2. Statistical plot showing consistent $90^{\circ}$ angle of propoduscarpus joint of Corallianassa acucurvata $n$. sp. and larger variable angle of Protocallianassa faujasi.

Type 1. - This type has a strongly calcified, robust propodus with short, squat and strongly curved fingers. On the cutting surface of the index one large triangular tooth is present dividing the finger into two more or less equal parts, both covered with fine denticles. On the dactylus two large rounded teeth cover the proximal half. The distal half is covered with fine denticles. On the propodus margin a relatively deep short groove is present at the base of the index. A number of pustules line the lower margin of this groove. The groove is directed in the extension of the cutting edge of the index. The upper margin is usually straight, the lower margin sinuous. In cross section the dactylus has an oval outline, the index is comma-shaped in cross section. Smaller claw with straight fingers of type 2 morphology.

Type 2. - The propodus of type 2 is usually less calcified than that of type 1 and bears more slender, stretched fingers. Both cutting edged of the elongated and sharply pointed dactylus and index are regularly covered with very fine denticles. Close to the base of the index a low triangular tooth is usually present on the cutting edge. The same groove on the propodus between the index and dactylus is present but is generally less pronounced. Number of setal pits, located in a row running just below and parallel to the cutting edge of the index, is almost twice compared to those of the two other types. Lower margin of propodus usually slightly sinuous and covered with forward-directed serrations to halfway the dactylus. In this type the morphology of the smaller chelae is nearly equal to the larger chelae.

Type 3. - The propodus is distinctly smaller and less calcified than that of the other types. Broadly based index has a triangular shape and is relatively flat in transverse section. Usually a faint ridge is present on the index, running parallel to the cutting edge. Cutting edge of index medially covered with sharp triangular tooth and fine denticles proximally and distally. Dactylus flat in transverse section, with sharp toothless cutting edge usually with two small, incisions: one close to the base, the other close to the tip. Lower edge of propodus convex, covered with forwardly directed serrations to halfway the dactylus. Groove on the propodus margin at the base of the index only faintly developed or not at all. Shape of smaller chelae is uneaqual to that of the larger chelae and resembles type 2.

For all three types the following can be observed; the inner side of propodus is smooth and in cross section slightly arched on central half to almost flat towards the margins. Outer side in cross section subcircularly arched and variably covered with granules, central parts of propodus usually smooth. The location of the setal pits is consistent whereas their number is slightly variable. Lower and upper margins of propodus very sharp and covered with forwardly directed serrations.

\section{Systematic palaeontology}

Infraorder Anomura H. Milne Edwards, 1832 Superfamily Thalassinoidea Latreille, 1831 Family Callianassidae Dana, 1852 


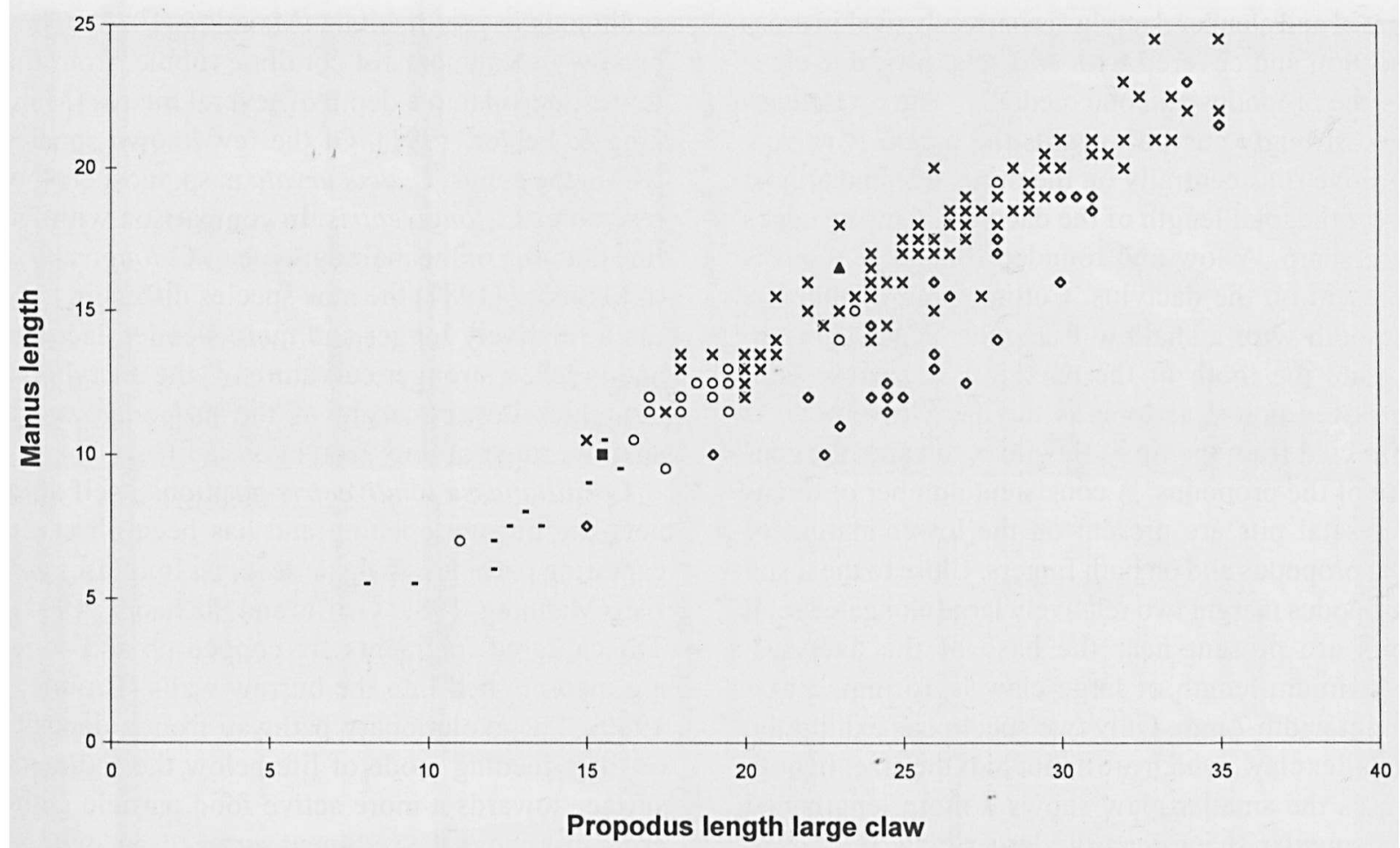

Fig. 3. Statistical plot showing manus and propodus length of Protocallianassa faujasi ( $\mathrm{x}=\mathrm{type} 1 ; 0=$ type $2,0=$ type 3 ), Corallianassa acucurvata (-), and Protocallianassa mortoni (⿶), and Protocallianassa russelli (4).
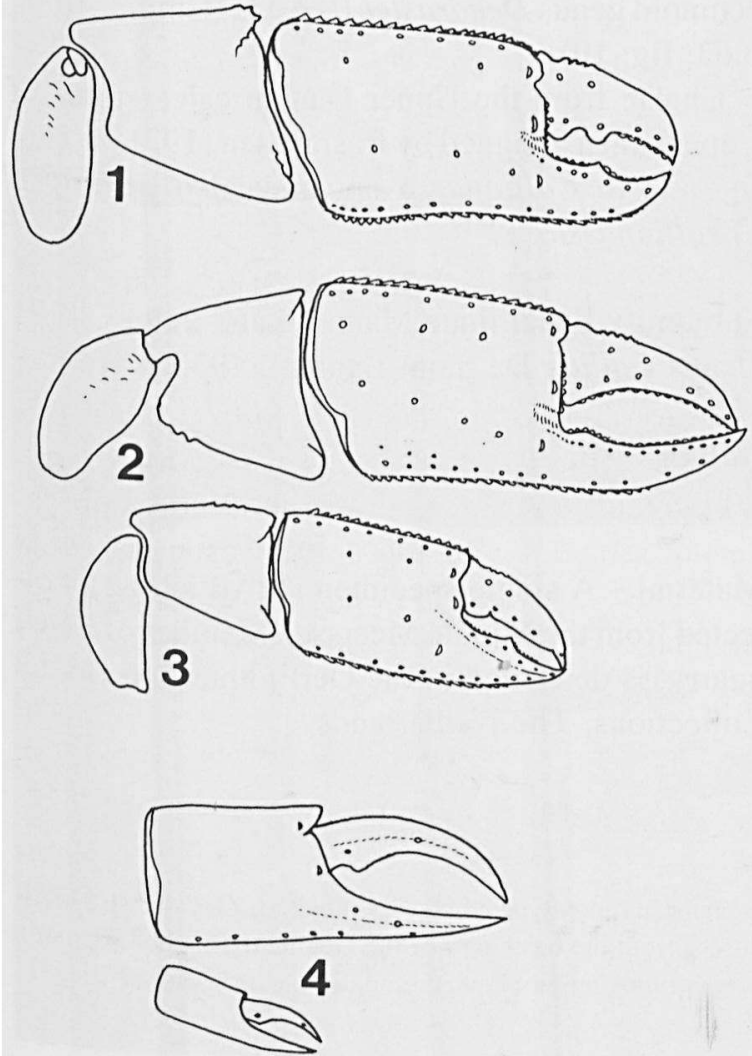

Subfamily Callichirinae Manning and Felder, 1991 Genus Corallianassa Manning, 1987

\section{Corallianassa acucurvata $\mathrm{n} . \mathrm{sp}$.}

Figs. 4.4, 5.1, 5.2

Diagnosis. - A relatively small, heterochelous species of Corallianassa with smooth elongated and curved fingers.

Description. - The proximal edge of the propodus is at an angle of $90^{\circ}$ to the long axis and the length of the upper margin is one fifth longer than wide, resulting in a rectangular shaped propodus. In cross section the propodus is almost flat on the inner side and arched on the outer side. A distinct identation is present on the distal margin of the propodus at the base of the dactylus. The elon-

Fig. 4. Protocallianassa faujasi large claw pereiopod morphotypes, $1=$ adult male, $2=$ female, 3 = immature male and 4 : Corallianassa acucurvata $\mathrm{n}$. sp. larger and smaller claw pereiopod morphology. 
gated and slender dactylus is narrowly oval in cross section and covered with two setal pits, one close to the propodus and one medially. The tip is sharp and strongly curved towards the index. A narrow groove runs centrally on the outer side and almost over the total length of the dactylus. Cutting edges are sharp. A low and rounded triangular tooth is present on the dactylus. Cutting edge of index is smooth with a shallow triangular depression opposite the tooth of the dactylus. A narrow faint groove, almost as long as the dactylus groove is directed from the tip of the index towards the centre of the propodus. A consistent number of circular setal pits are present on the lower margin of the propodus and on both fingers. Close to the distal propodus margin two relatively large elongated setal pits are present near the base of the dactylus. Maximum length of large claw is $16 \mathrm{~mm}$, maximum width $7 \mathrm{~mm}$. Only two specimens exhibit the smaller claw, which are about half the size. In both cases the smaller claw shows a more lengthened rectangular shape than the larger claw.

Material. - The holotype (MAB k1061), part of the first pereiopod pair with large right claw and small left claw, from the Emael Member, CBRRomontbos quarry (leg. J. Jagt); paratypes (MAB k0537) from the lower Nekum Member, CBRRomontbos quarry; (MAB k0613) from the upper Meerssen Member from the ENCI quarry. All deposited in the Oertijdmuseum Collections, Boxtel, The Netherlands.

Etymology, - The name is a combination of the Latin words acutus (sharp) and curvatus (curved) referring to the shape of the fingers.

Remarks. - Recent species of Corallianassa are known from the Indo-West Pacific, Caribbean, Western Atlantic and possibly the Red Sea (Manning, 1988, 1992). Species have been recorded from carbonate muds, seagrass beds of shallow lagoons, and coralline sands. Most records are from coarse sediments in reef habitats (Manning, 1987). They burrow in fragments of coralline rubble, from the lower intertidal to a depth of several metres (Manning \& Felder, 1991). Of the few known species within the genus, C. acucurvata n. sp. most closely resembles $C$. longiventris. In comparison with the line drawing of the male syntype of $C$. longiventris in Manning (1987) the new species differs in having a relatively longer and more slender dactylus and index, a stronger curvature of the dactylus, a straighter lower margin of the propodus and a shallow ridge on the dactylus.

Corallianassa longiventris positions itself at or near the burrow opening and has been observed capturing particles of algae, seagrass, molluscs and fish (Manning, 1987; Griffis and Suchanek, 1991). The captured fragments are copped up and some are incorporated into the burrow walls (Bromley, 1990). The evolutionary pathway from a depositor filter-feeding mode of life below the sediment surface towards a more active food particle gathering just above the sediment surface is an expression of very strong competition in a restricted habitat. Another example of such an evolutionary pathway is seen in the origin of the clypeasteroid echinoid genus Dendraster (see e.g., Ghiold, 1984, p.63, fig. 10).

Chelae from the Upper Danian calcarenites of Copenhagen assigned by Rasmussen (1971, p. 206, fig. 11) to Callianassa sp. may also belong to Corallianassa.

Subfamily Eucallïnae Manning and Felder, 1991 Genus Calliax De Saint Laurent, 1973

\section{Calliax? sp.}

Fig. 5.3

Material - A single specimen (MAB k1982), collected from the Middle Meerssen Member of ENCI quarry, is deposited in the Oertijdmuseum Boxtel Collections, The Netherlands.

Fig. 5. 1, Corallianassa acucurvata, holotype MAB k1061, $\times 2 ; 2$, C. acucurvata, paratype MAB k0519, $\times 2 ; 3$, Calliax? sp., MAB k1982, ×5; 4, Unidentified callianassid ×2 (MAB k2281, leg. Guido Busch) from the basal part of the Geulhem Member (Danian), Curfs quarry; 5, 6, Natural size flint burrows with in situ Protocallianassa faujasi larger claw pereiopods, Nekum Member, leg. L. Indeherberghe. 


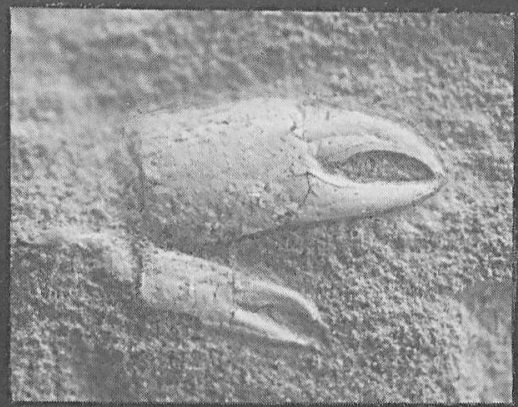

1

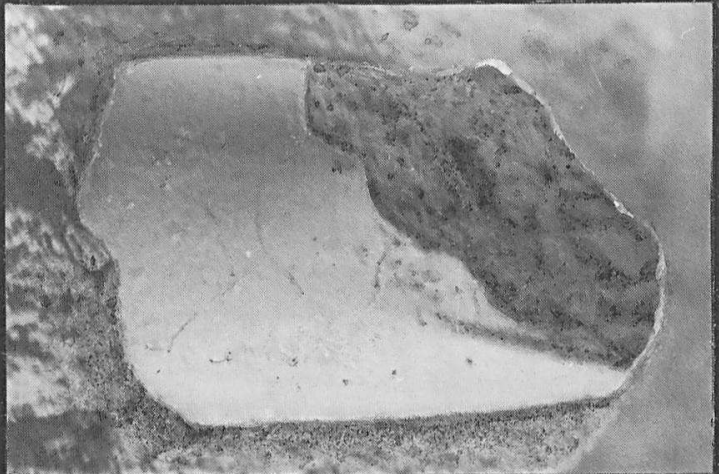

3

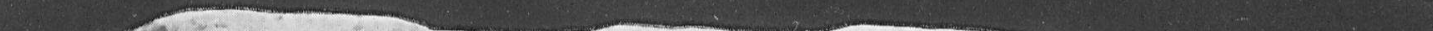

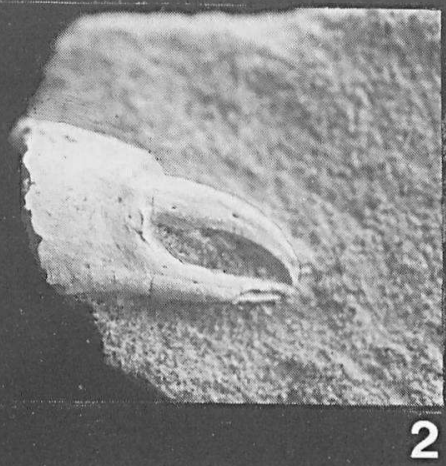

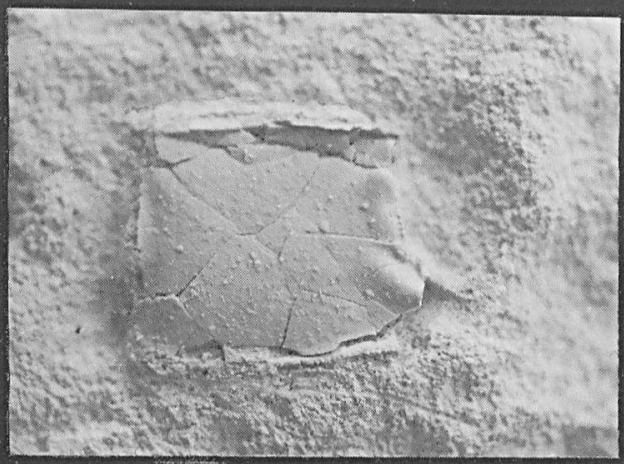

4

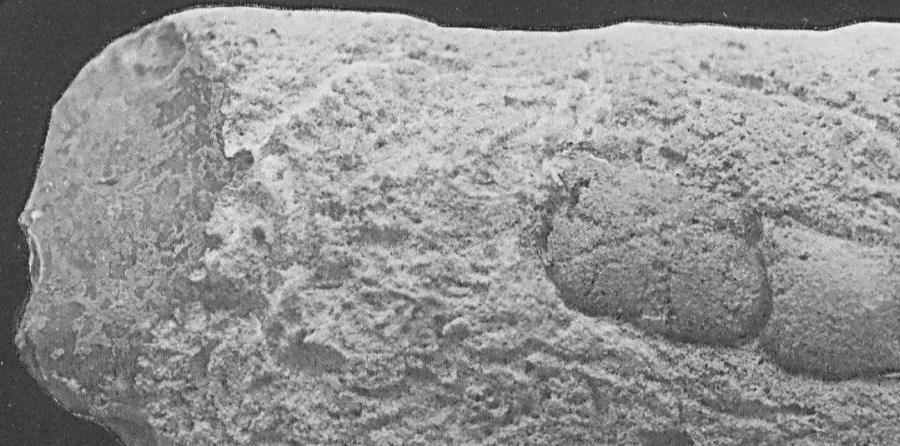

5

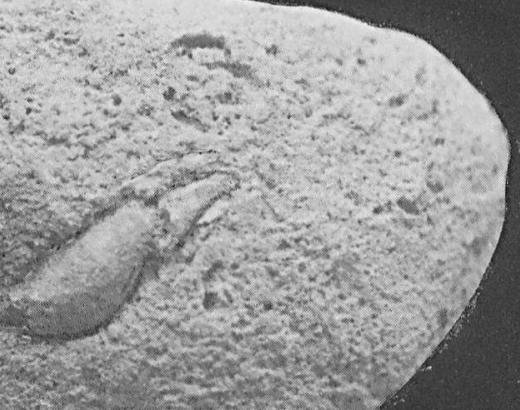

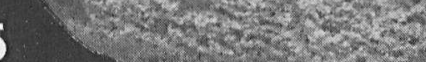

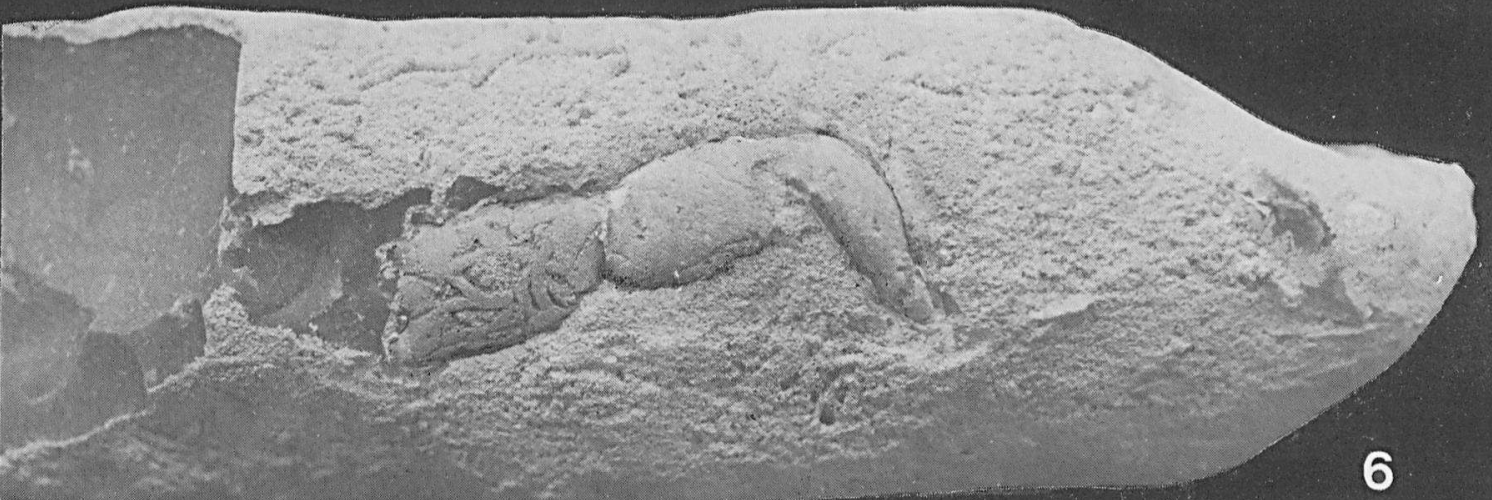




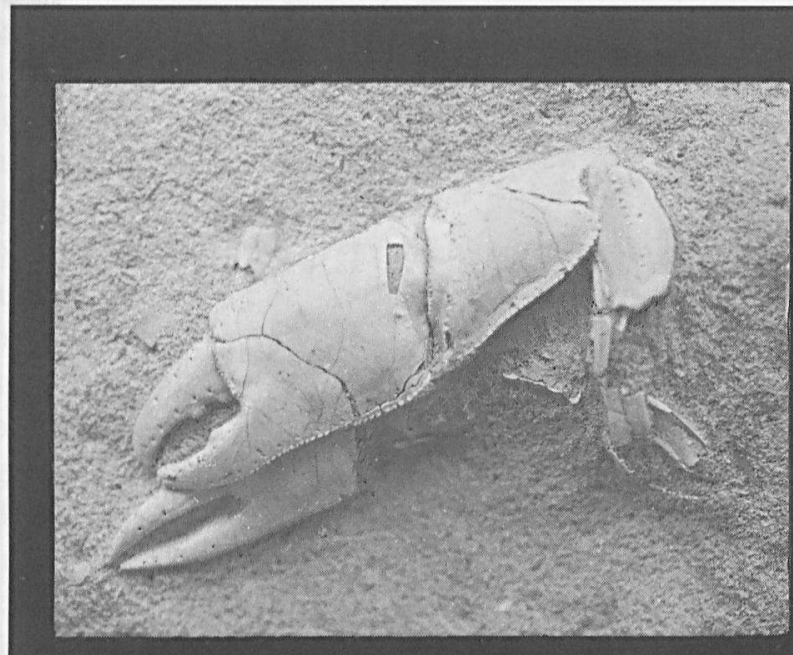

1

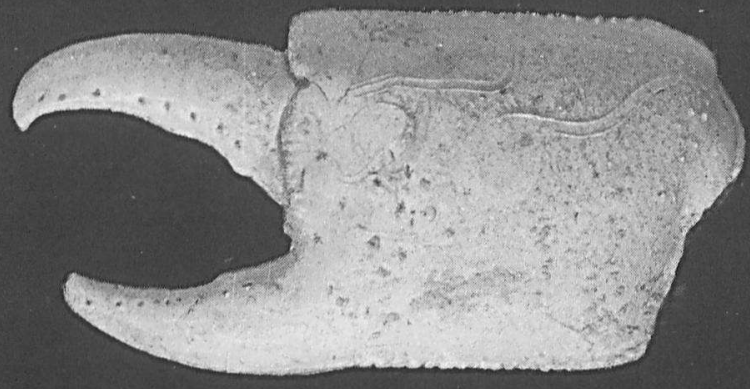

3

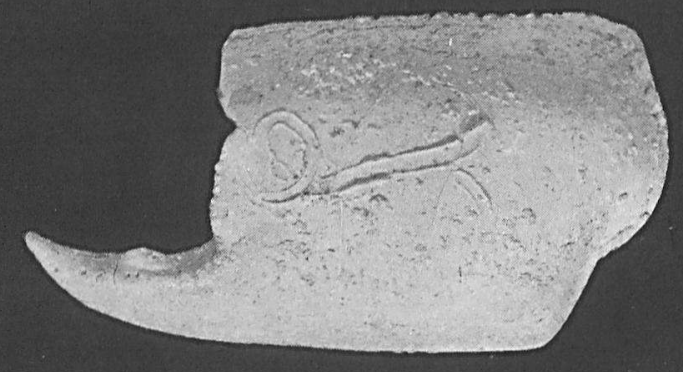

5

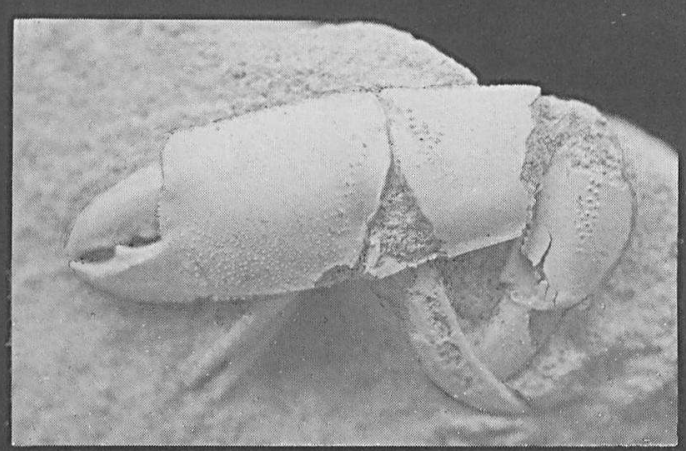

2

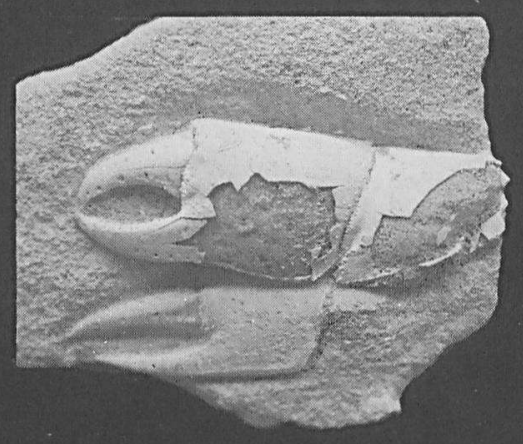

4

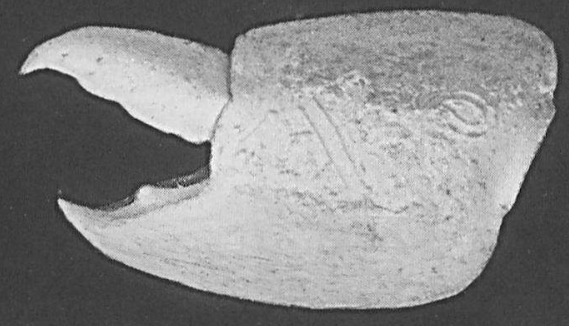

6

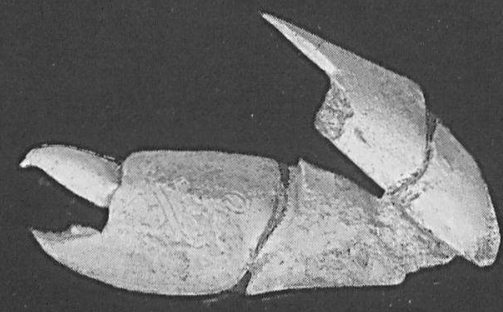

7 
Remarks. - The incomplete specimen only exhibits the propodus without the dactylus. The straight angle of the proximal margin places this specimen within the Callianassidae. General morphology of the propodus and especially of the short, triangular fixed finger most closely resemble members of the Eucalliinae (see Manning \& Felder, 1991, p. 783). In the absence of other pereiopod elements and more material this specimen provisionally is placed within Calliax.

Recent members of the Eucalliinae occur in carbonate sand-silt substrates, from the intertidal to shallow subtidal depths (Manning \& Felder, 1991). The same habitat has been recorded for the middle Meerssen Member (Fraaye, 1996a, b).

Another probable member of this subfamily is Callianassa saetosa from the Maastrichtian of Chile (Förster \& Stinnesbeck, 1987).

\section{Burrows}

Although late Cretaceous sediments rich in thalassinidean burrows and callianassid pereiopods are numerous (e.g., Aguirre-Urreta, 1989; Feldmann et al., 1995; Förster, 1987; Píckett et al., 1971; Rasmussen, 1971), only three late Cretaceous examples of callianassid remains within their burrows are known (Beikirch \& Feldmann, 1980; Mertin, 1941; Waage, 1968). Two complete pereiopods of the larger claw of Protocallianassa faujasi from the Nekum Member, preserved in a flint burrow (Figs. 5.5, 5.6) were found by Mr. L Indeherberge. One of the specimens shows a secondary chondritic burrowing within the propodus (Fig. 5.6). A silicified turnaround contained one incomplete propodus. Many burrows in the Emael Member are preserved in flint (see Zijlstra, 1988, p. 347 , fig. $3 ;$ p. 353 , fig. 7). Flint precipitation in and around burrows strongly decreased in the Nekum and Meerssen Members." Relatively small burrow systems lined with numerous black and brown coloured fish remains (Fig. 7.2) are most abundant in the Meerssen Member.

Thalassinidean shrimp rely on self-constructed burrows for a wide variety of needs including shelter, reproduction, and feeding. Recent burrowing thalassinidean shrimps occur in any depth from the littoral zone down to some hundreds of metres (Müller, 1984). Except for a larval phase which may be pelagic, most thalassinidean shrimps spend their entire life within a self-constructed burrow (Griffis \& Suchanek, 1991). In order to be able to classify the burrows of Protocallianassa faujasi into a certain morphological group and hence to derive its mode of feeding, the burrow architecture-trophic mode model of Griffis and Suchanek (1991, p. 173) was used. Despite high levels of morphological variation this model classifies thalassinidean burrows into six major groups based on the presence or absence of prominent features such as surface sediment mounds, seagrass deposits, and the in- and external morphological characteristics of the burrows. Based on the presence of long, straight shafts with few side shafts (Fig. 7.1), combined with often complex to dichotomous branched parts (Fig. 7.3), subcircular turnarounds and short dead-ends or resting chambers (see Pickett et al., 1971) the burrows from the sediments of the late Maastrichtian Emael and Nekum Members in the Maastrichtian stratotype area are assigned to type 4 of Griffis and Suchanek (1991).

Corállianassa acucurvata n. sp. most closely resembles recent $C$. longiventris and its ecological strategy was probably similar. $C$. longiventris belongs to the group of "seagrass harvesters". Type 3 burrows of Griffis and Suchanek (1991) are attributed to them. These burrows are characterized by the presence of seagrass and other organic material in burrow chambers and linings. In the very shallow waters of the Virgin Islands the burrow system of this species attain a depth of 150 $\mathrm{cm}$, a horizontal spreading of $200 \mathrm{~cm}$, and a diameter of $30 \mathrm{~mm}$. Both type 3 and 4 burrow systems

$\leftarrow$

Fig. 6. 1, Protocallianassa faujasi type 1, MAB k2282, middle Nekum Member, Nekami quarry, $\times 1 ; 2$, faujasi type 3, MAB k1985, lower Nekum Member, Marnebel quarry, $\times 1.5 ; 3, P \times$ faujasi type 2 with epizoic serpulids, MAB k2157, lower Nekum Member, Nekami quarry, $\times 2 ; 4, P$, faujasi type 2, MAB k1064, middle Nekum Member, Romontbos quarry, $\times 1 ; 5, P \times$ faujasi type 1 with epizoic serpulíds, MAB k1986, lower Nekum Member, Marnebel quarry, ×2;6,7,P. faujasi type 3 with epizoic serpulids, lower Nekum Member, ENCI quarry, $6=\times 2,7=\times 1$ 


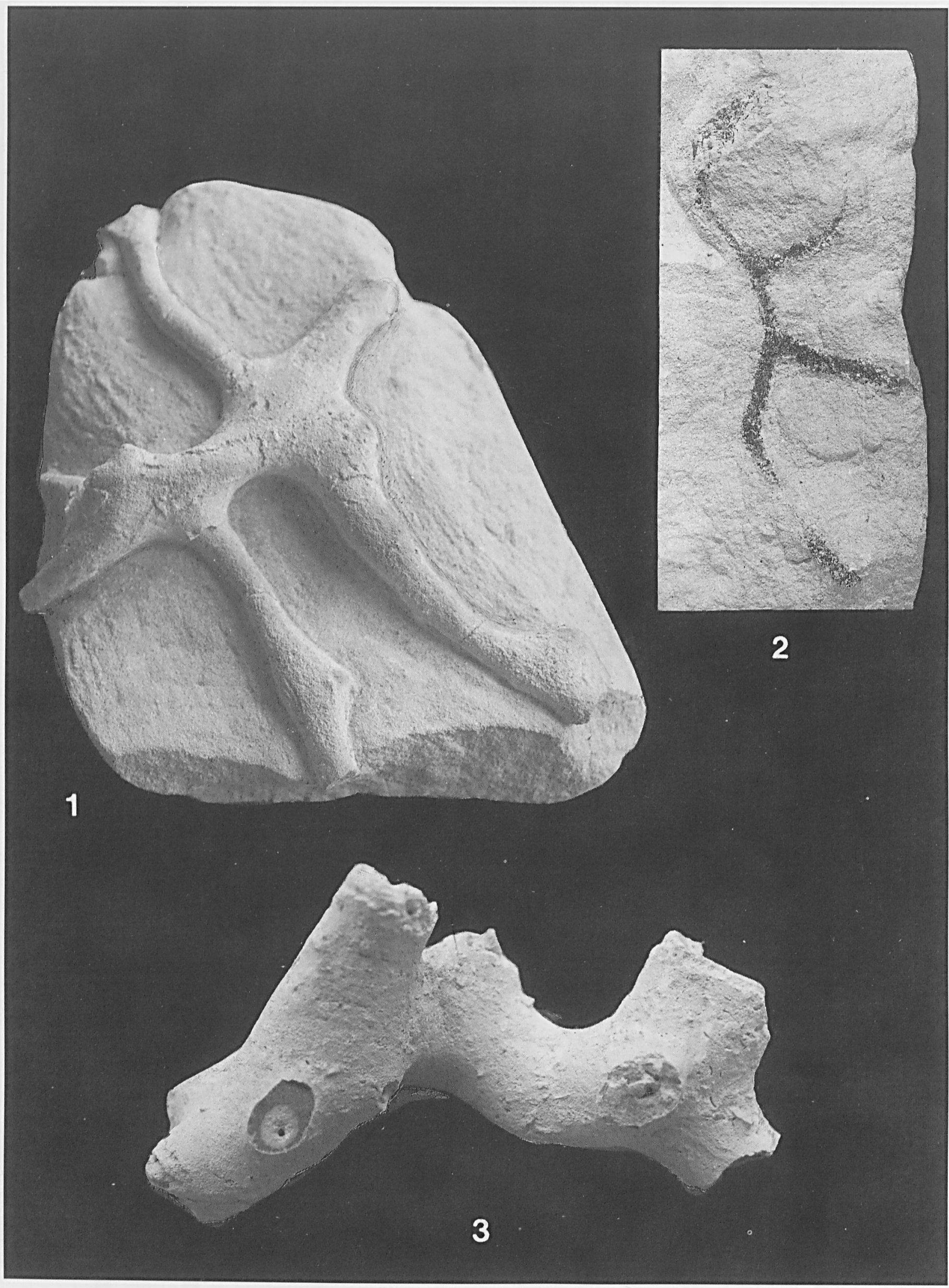


do not include surface sediment mounds (Griffis \& Suchanek, 1991).

Thalassinidean bioturbation drastically influences processes of sedimentation, rutrient cycling and fossilisation. The rapid burial of coarse fragments and the continuous recycling of the finer particles subject the finer fragments to longer periods of exposure to destructive processes operating on the seafloor, in particular attack by microborers (Tudhope \& Scoffin, 1984). The deep burrow systems of type 3 (seagrass harvesters) and type 4 (filter/suspension feeders) increase bacterial numbers and activity by oxygenation of the sediment and organic burrow wall surfaces. The intensive collection and trapping of organic particles by the seagrass harvesters also strongly influences the nutrient cycles in removing for example the carbon and nitrogen from surrounding trophic levels (Griffis \& Suchanek, 1991).

The common occurrence of seagrasses and thalassinidean burrows and the apparently poor fossil content of the upper Meerssen Member in the Maastrichtian type area could, at least in part, be explained by these complex thalassinidean bioturbation processes.

\section{Conclusions}

Comparing Figs. 2, 3, 4.1-4.3 and 6, three pereiopodal types can be distinguished. Types 1,2 and 3, are all assigned to Protocallianassa faujasi because of their consistent co-occurrence, the identical morphology of the smaller claw pereiopod, and the similar morphology of the larger claw pereiopod except for the propodus. The presence of three morphotypes within what appears to be a single species is attributed to sexual dimorphism and ecdysis stages. Analogous to recent species, type 1 is considered to represent the adult male. The robust propodus is most heavily calcified and has a conspicuous, relatively deep notch at the base of the index. This notch could have played an important role in mating behaviour of the males (R.M. Feldmann personal commun.). Type 2 consequently is the female type. The propodus is less calcified and robustly built, and lacks strong teeth on both fingers. The notch at the base of the index is less striking. Specimens of type 3 are regarded as immature and most probably of males. This type is significantly less calcified. Both index and dactylus are relatively broader at the base and leave no space for a distinct notch at the base of the index. Our argument regarding sex of this type is based upon the presence of a large triangular tooth on the index, conform the adult male type 1 . The fact that fewer female types have been found, with no immature female types, probably is the effect of selective collection and preservation.

Ever since Mertin's (1941) detailed study and that of Glaessner (1969), the systematics of the genus Protocallianassa has remained confusing and inconsistent. The present study shows that, in view of the morphological variation of Protocallianassa faujasi, species have to be synonymized. Schlüter (1862) already noted the close similarity of $P$. antiqua, $P$. archiaci and $P$. faujasi. Fritsch and Kafka (1887, p. 42, fig. 63) illustrated two chelae morphotypes (our types 1 and 3 , interpreted herein as adult and juvenile male ecdysis moulds, respectively) of Callianassa antiqua (= Protocallianassa faujasi).

Another widely recorded late Cretaceous species which is most probably conspecific with $P$. faujasi is $P$. mortoni, known from many localities in North America. Toolson and Kues (1996), mentioned the wide range of variation of $P$, mortoni and close relationship with $P$. faujasi. They remarked that these two species differed in details only. A comparable biometric and morphological study of $P$. mortoni assemblages, as already hinted by Bishop (1985) and Toolson and Kues (1996) is needed to settle this matter.

The question arises whether the demise of the monogeneric subfamily Protocallianassinae near the $\mathrm{K} / \mathrm{T}$ boundary and the simultaneous rise of at

$\leftarrow$

Fig. 7. Fragments of typical thalassinidean flint burrow systems from the Emael (1) and Nekum (2) Members and a burrow system from the Meerssen Member lined with fish remains. 


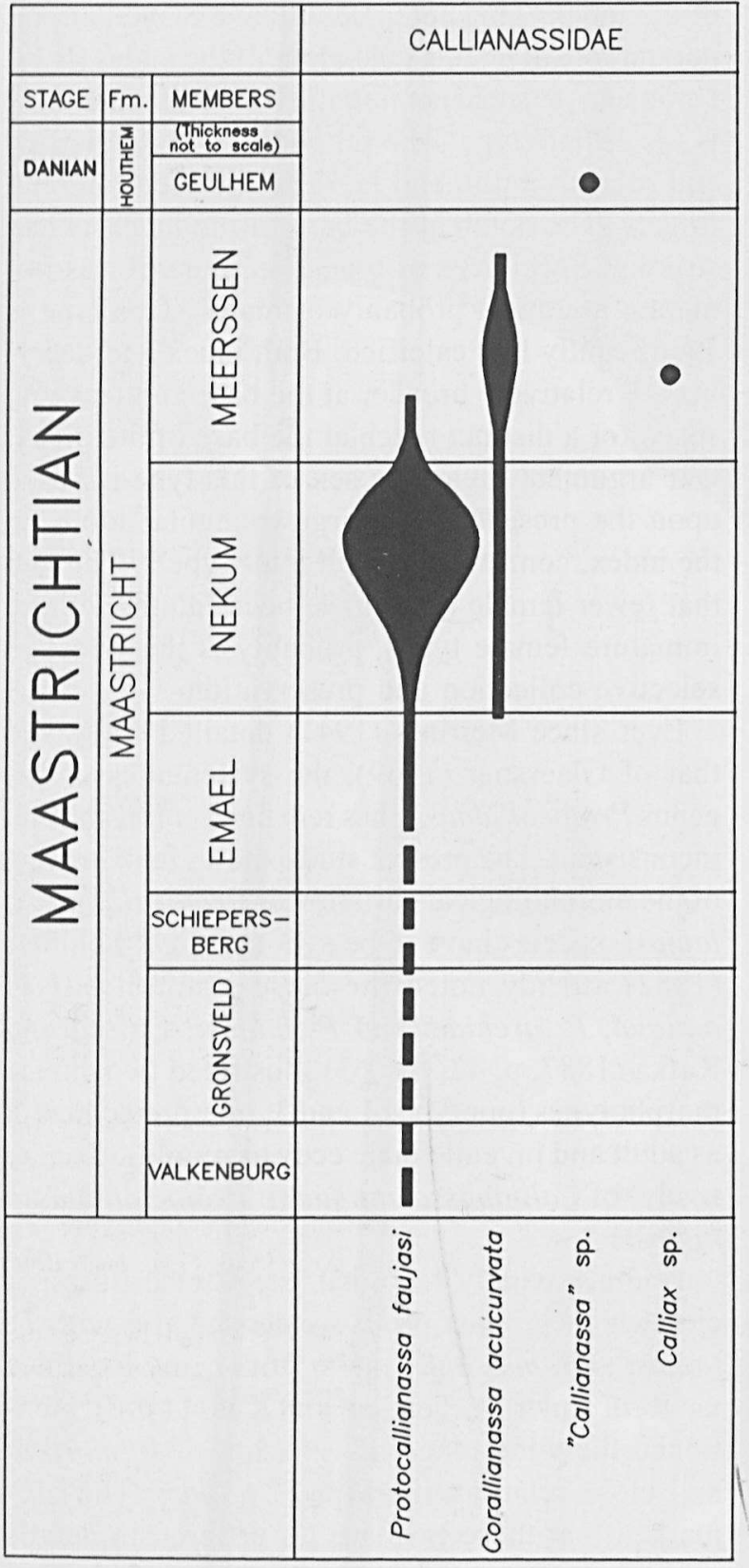

Fig. 8. Stratigraphical range of all known callianassids in the type Maastrichtian area.

least three other subfamilies (Callianassinae, Callichirinae and Cheraminae), in the same habitat, can be related to a change in diet and/or foodgathering. The worldwide emergence of seagrasses at the end of the Cretaceous (Brasier, 1975; Den Hartog, 1971; Voigt, 1981) and the simultaneous strong community competition within the habitat between mean low water and 12 metres depth (Brasier, 1975) could be the reason why the place of the suspension-feeding Protocallianassa was taken over by Corallianassa and others, which feed actively on detritus. Such a changeover model of benthic filter-feeding organisms by detritus feeders, related to an extraterrestrial impact event at the K/T boundary, was brought forward by Sheenan and Hansen (1986). Their scenario of detritus feeders successfully surviving the $\mathrm{K} / \mathrm{T}$ boundary event while photosynthesis dependent organisms vanished is not supported by our results. The Protocallianassa-Corallianassa changeover in the Maastrichtian stratotype area occurred between the horizon of Caster and the Ivf- 4 subunit of the Meerssen Member (see Fig. 8), c. 100,000 yrs prior to the $\mathrm{K} / \mathrm{T}$ boundary in this region (Vonhof \& Smit, 1996).

\section{Acknowledgments}

We thank G. Busch (Herzogenrath, Germany), B.A. Fraaije (London, UK), L. Indeherberghe (Zonhoven, Belgium), M. Kuypers (Ittervoort) and J.H.G. Peeters (Natuurhistorisch Museum Maastricht), for access to and loan of specimens from their collections, R.M. Feldmann, J.W.M. Jagt, A. Kempers and an anonymous reviewer for suggestions leading to improvement of this paper and W. den Hartog, J. Luteyn and T. van Hinte (State University Utrecht) for technical assistance. Special thanks are extended to R. Veldman.

\section{References}

Aguirre-Urreta MB. 1989. The Cretaceous decapod Crustacea of Argentina and the Antarctic Peninsula. Palaeont. 32: 499-552

Bauer R. 1980. Functional morphology, adaptive value, and the systematic significance of grooming behavior in the Decapod Crustacea. 26th Congres Geologique International Abstracts 1:155.

Beikirch DW, Feldmann RM. 1980. Decapod crustaceans from the Pflugerville Member, Austin Formation (Late Cretaceous: Campanian) of Texas. J. Paleont. 54: 309-324

Bishop GA. 1985. Fossil decapod crustaceans from the Gammon Ferruginous Member, Pierre Shale (Early Campanian), Black Hills, South Dakota. J. Paleont. 59: 605-624

Brasier MD. 1975. An outline history of seagrass communities. Palaeont. 18: 681-702

Bromley RG. 1990. Trace fossils; biology and taphonomy. Special topics in palaeontology 3. Unwin Hyman, London. $280 \mathrm{pp}$

Collins JSH, Fraaye RHB, Jagt JWM. 1995. Late Cretaceous anomurans and brachyurans from the Maastrichtian type area. 
Acta Pal. Polonica 40: 165-210

Den Hartog C. 1971. Origin, evolution and geographical distribution of the sea-grasses. Verh. Kon. Ned. Akad. Wetensch. 59: $12-38$

Dworschack PC, Pervesler P. 1988. Burrows of Callianasssa bouvieri Nobili, 1904, from'Safaga (Egypt, Red Sea) with some remarks on the biology of the species. Senckenb. mar. 20: $1-17$

Feldmann RM. 1991. Decapod Crustacea from the Tapui Glauconitic Sandstone (Bortonian: Middle Eocene) in the Waitaki Valley, South Island, New Zealand. New Zeal. J, Geol. Geoph. 34: 17-22

Feldmann RM, Wilson MT. 1988. Eocene decapod crustaceans from Antarctica. Geol. Soc. Am. Mem. 169; 465-488

Feldmann RM, Casadio S, Chirino-Galvez L,Aguirre-Urreta M. 1995. Fossil decapod crustaceans from the Jagüel and Roca Formations (Maastrichtian-Danian) of the Neuquên Basin, Argentina. Pal. Soc. Mem. 43: 1-22

Feldmann RM, Zinsmeister WJ. 1984. First occurrence of fossil decapod crustaceans (Callianassidae) from the McMurdo Sound Region, Antarctica. J. Paleont. 58: 10411045

Förster R, Stinnesbeck W. 1987. Zwei neue Krebse, Callianassa saetosa n. sp. und Homolopsis chilensis $\mathbf{n}$. $\mathbf{~ s p . ~}$ (Crustacea, Decapoda) aus der Oberkreide Zentral-Chiles. Mitt. Bay. Staatssamml. Paläont. Hist. Geol. 27: 51-65

Fraaye RHB. 1996a. Evolution of Meso- and Cenozoic decapod crustaceans and their role in former ecosystems. University of Utrecht (unpubl. PhD thesis).

Fraaye RHB. 1996b. A new Tethyan migrant: Cretachlorodius enciensis . gen., n. sp. (Crustacea, Decapoda), from the type Maastrichtian of The Netherlands. J. Paleont. 70: 293-296

Fraaye RHB. 1996c. Two new crabs, Graptocarcinus maastrichtensis. and Caloxanthus kuypersi (Crustacea, Decapoda), from the type Maastrichtian of The Netherlands. J. Paleont. 70: 463-465

Fraaye RHB. 1996d. Late Cretaceous swimming crabs: radiation, migration, competition, and extinction. Acta Geol. Polon. 46(1997): 269-278

Fraaye RHB, Collins JSH. 1987. A new crab, Prehepatus werneri (Crustacea, Decapoda) from the Maastrichtian of The Netherlands. J. Paleont. 61: 549-551

Fritsch A, Kafka J. 1887. Die Crustaceen der Böhmischen Kreideformation. Selbstverlag Prague 53 pp.

Ghiold J. 1984. Adaptive shifts in clypeasteroid evolution feeding strategies in the soft-bottom realm. N. Jahrb. Geol. Paläont. Abh. 169: 41-73

Glaessner MF. 1969. Decapoda, p. R399-R533. In: Moore RC, ed. Treatise on Invertebrate Paleontology, Part R, Arthropoda 4, volume 2. Geol. Soc. Am. \& Kansas Press Lawrence

Griffis RB, Suchanek TH. 1991. A model of burrow architecture and trophic modes in thalassidinean shrimp (Decapoda: Thalassinidea). Mar, Ecol. Prog. Ser, 79; 171-183

Jagt JWM, Collins JSH, Fraaye RHB. 1991. A new late Maastrichtian xanthid crab from southern Limburg (The Netherlands). Cret. Research 12: 553-560

Jagt JWM, Fraaye RHB, van Bakel BWM. 2000. Late Cretaceous decapod crustacean faunas of northeast Belgium and the southeast Netherlands. Studi e Ricerche, Museo Civico G. Zannato, Montecchio Maggiore: 37-42

Manning RB. 1987. Notes on the Western Atlantic Callianassidae (Crustacea: Decapoda: Thalassinidae). Proc. Biol. Soc. Wash. 100: 386-401

Manning RB. 1988. The status of Callianassa hartmeyeri Schmitt, 1935, with the description of Corallianassa xutha from the West Coast of America (Crustacea, Decapod, Thalassinidae). Proc. Biol. Soc. Wash. 101: 883-889

Manning RB. 1992. A new genus for Corallianassa xutha Manning (Crustacea: Decapoda: Callinassidae), Proc. Biol. Soc. Wash. 105: 571-574

Manning RB, Felder D.L. 1991. Revision of the American Callianassídae (Crustaceax Decapoda: Thalassinidae), Proc. Biol. Soc. Wash. 104: 764-792

Mertin H. 1941. Decapode Krebse aus dem Subhercynen und Braunschweiger Emscher und Untersenon, sowie Bemerkungen über einige verwandte Formen in der Oberkreide. Nova Acta Leopoldina 10: 149-264

Mulder EWA. 1981. Een bìjdrage tot de karakterisering van de kreeft Callianassa faujasi Desmarest. Nat.hist. Maandblad 70: $170-174$

Miiller P. 1984. Decapod Crustacea from the Badenian. Geol. Hung. Ser, Palaeont. 42: 1-137

Pickett TE, Kraft JC,.Smith K. 1971. Cretaceous burrows Chesapaeke and Delaware Canal, Delaware. J. Paleont. 45: 209-211

Poore GCB. 1975. Systematics and distribution of Callianassa (Crustacea, Decapoda, Macrura) from the Port Philip Bay, Australia, with description of two new species. Pacific Sci. 29: 197-209

Rasmussen HW. 1971. Echínoid and crustacean burrows and their diagenetic significance in the Maastrichtian-Danian of Stevns Klint, Denmark. Lethaia 4: 191-216

Roberts HB. 1962. The Upper Cretaceous decapod crustaceans of New Jersey and Delaware. New Jersey Geol. Surv. Bull. 61: 163-191

Sakai K. 1969. Revision of Japanese callianassids based on the variations of larger cheliped in Callianassa petalura Stimpson and C. Japonica Ortmann (Decapoda: Anomura). Publ. Seto Mar. Biol. Lab. 17: 209-252

Schlüter C. 1862. Die Macruren Decapoden der Senon- und Cenơman-Bildungen Westphalens. Zeitschr. dt. Geol. Ges. 14: $702-749$

Schweizer Hopkins C, Feldmann RM. 1997. Sexual dimorphism in fossil and extant species of Callianopsis de Saint Laurent. J. Crust. Biol. 17: 236-252

Sheenan PM, Hansen TA. 1986. Detritus feeding as a buffer to extinction at the end of the Cretaceous. Geology: 868-870

Toolson EK, Kues BS. 1996. Decapod crustaceans from the Semilla Sandstone Member, Mancos Shale (Upper Cretaceous), North-Central New Mexico. J. Paleont. 70: 111-116

Tshudy DM, Feldmann RM. 1988. Macruran decapods, and their epibionts, from the López de Bertodano Formation (Upper Cretaceous), Seymour Island, Antarctica. Geol. Soc. Am. Memoir 169: 291-301

Tudhope AW, Scoffin TP. 1984. The effects of Callianassa bioturbation on the preservation of carbonate grains in Davies 
Reef Lagoon, Great Barrier Reef, Australia. J. Sed. Petr. 54: 1091-1096

Vega FJ, Feldmann RM, Sour-Tovar F. 1995. Fossil crabs (Crustaceax Decapoda) from the Late Cretaceous Cárdenas Formation, East-Central Mexico. J. Paleont. 69: 340-350

Voigt E. 1981. Upper Cretaceous bryozoan-seagrass association in the Maastrichtian of The Netherlands. In: Larwood GP, Nìelsen C, eds. Recent and Fossil Bryozoa. Olsen \& Olsen, Fredensborg, Denmark: 281-298

Vonhof IIB, Smit J. 1996. Strontium-isotope stratigraphy of the type Maastrichtian and the Cretaceous/Tertiary boundary in the Maastrichtian area (SE Netherlands). Geol. Mijnb. 75: 275-282
Waage KM. 1968. The type Fox Hills Formation, Cretaceous (Maestrichtian), South Dakota. Peabody Mus. Nat. Hist. Yale Univ. Bull. 27: 1-171

Zijlstra HJP. 1988. Early diagenetic silica precipitation, in relation to redox boundaries and bacterial metabolism, in Late Cretaceous chalk of the Maastrichtian type locality. Geol. Mijnb. 66: 343-355

Zijlstra HJP. 1994. Sedimentology of the Late Cretaceous and Early Tertiary (Tuffaceous) Chalk of Northwest Europe. Geologica Ultraiectina 119: 192 pp.

Received: 4 November 2000 